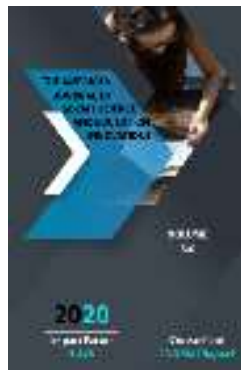

\title{
The Role Of Mahalla Civil Society Institutes In Increasing The Youth's Social Activeness In The Family
}

\author{
Salokhiddinova Gazalkhon Bekmirzayevna \\ Senior Teacher At The Department Of Pedagogy And Psychology, Uzbek State World \\ Languages University, Tashkent, Uzbekistan
}

\begin{abstract}
Journal Website: http://usajournalshub.c om/index,php/tajssei

Copyright: Original content from this work may be used under the terms of the creative commons attributes 4.0 licence.
\end{abstract}

\section{ABSTRACT}

This article scrutinizes organizing cooperation among civil society institutions to encourage the social activeness of youth in families, specifically, the activities of mahalla institutions, increasing the youth activeness in mahalla, education establishments, as well as in labor unions, the responsibilities of mahalla in organizing events aiming to develop the patriotism and the awareness of events happening in the country.

\section{KEYWORDS}

Mahalla, family, neighborhood, educational institutions, public holidays.

\section{INTRODUCTION}

"One very important issue which never leaves the daily plan for us is concerning the growing new generation and the upbringing of our children. Therefore, the child upbringing and working with the youth should stay the most profound topic for us."

Mirziyoyev SH.M.

The issue of improving the performance efficiency of civil society institutions is cared separately according to the decree of the President of the Uzbekistan Republic "On the policies of rehabilitating social-cultural environment in the society, supporting mahalla (neighborhood) institutions more and upgrading the systems of working with family and women" (P.F-5938) from February-18, 2020, on establishing the work of the Ministry of Supporting Mahalla and Family. The decree sets important tasks for 
the social support of young people, their upbringing as active members of society, support for family business, further development of neighborhood institutions.

Uzbekistan became the first country in the world to establish a Ministry of Mahalla (Neighborhood) and Family. The goal is to further support community and family activities. Indeed, ensuring the cooperation of family-neighborhood-educational institution in the upbringing of a healthy generation in our country is a witness of results. The priorities of our government in this regard are as follows:

- Improving the legal framework for cooperation between families, neighborhood, educational institutions, strengthening the methodological framework aimed at boosting cooperation;

- Increasing the social activeness of the youth and parents in the family;

- $\quad$ Educating students, upbringing them, supporting talented youth, directing them to the profession according to their interests;

- $\quad$ Supporting the families in need of social protection materially and morally;

- Improving the effectiveness of preventive measures to prevent juvenile delinquency and staying neglected among adolescents and young people;

- $\quad$ Promoting a healthy lifestyle among young people, preparing them for a healthy family by involving them in physical culture and sports;

- Improving the content of spiritual and educational activities aimed at upbringing perfect generation and creating a mechanism to increase their effectiveness;

- Effective use of mass media and modern information and communication technologies in upbringing a healthy generation;

The content of these priorities, aimed at increasing the effectiveness of cooperation between the family, community and educational institutions, requires the implementation of the following effective forms, methods and tools.

\section{MATERIALS AND METHODS}

Development and implementation of model scenarios and recommendations for the development of a sense of patriotism among young people in the community and in educational institutions, as well as in the workforce, and a sense of involvement in events in the country, such as:

- Events related to fostering a sense of respect for the national flag, anthem and other national symbols;

- To hold admissions ceremonies to the ranks of the pupils, students, and labor communities;

- Public holidays, events that reflect our social life and others are an important basis for strengthening the spiritual foundation of a healthy generation;

Also, developing booklets, commentaries on laws, handouts and leaflets, containing legal information in simple, fluent language, aimed at improving the legal knowledge of preschoolers and students, based on the psychological characteristics of young people, in collaboration with teachers, psychologists and lawyers, and its implementation will play an important role in the methodological support of cooperation in this area.

In the formation of a healthy generation in the above areas, modern forms of education and upbringing practices, such as competitions, seminars - trainings, question and answer evenings, training seminars, debates, meetings, raids, roundtables, dialogue, scientific conferences, sports 
competitions, book fairs, presentations, poetry evenings, friendship festivals are a guarantee of effectiveness in increasing their social activity, preparing them for a healthy family, forming a culture of healthy living.

It is natural these educational activities based on the program of mutual cooperation can be effective only if they are organized in cooperation with parents, teachers and the general public, taking into account the age and psychological characteristics, social life, family conditions, opportunities and interests of young people, as well as the nature of state youth policy.

In the upbringing and formation of a healthy generation, it is a requirement of the time to have pedagogical, psychological and medical knowledge for the officials of all institutions of society engaged in the education and upbringing of young people.

Strengthening the focus on education and upbringing, effective implementation of laws and documents, directives adopted by our government in this regard requires the activities of family, community, school cooperation to have a unique pedagogical system, style and form.

The events should be thorough in all respects, as well as pedagogically and psychologically assembled suitable for the participants age, logically deep, interesting and visual, impressive, popular, practically short and concise, aesthetically wide-ranging.

The topics of cooperation events could be "For healthy youth", "Thanks to your parents", "Excellent behavior", "Healthy mind in healthy body", "The lake of kindness", "The honor of girls", "Forty crafts are not enough for a man", "My son - my defense", "Life - a master, people - a teacher", "Uzbekistan is my motherland!", "National duties and responsibilities", "Family lessons", "Ethics of family", "Peaceful family - peaceful neighborhood", "In the threshold of independent life", "The army- the school of the man", "The happiness of family is the happiness of the motherland", "Sports-loving family", "Our family's tunes", "The motherland starts from doorstep", "Who are we?".

Sports and various cultural events held in the neighborhood provide an opportunity for adults to explore the aspirations and abilities of young people.

In the implementation of the above educational, organizational, methodological policies to the real life, each citizen, family, neighborhood and school implements its own conditions, practical and educational work in the directions of

- "school-family-neighborhoodcommunity";

- "family - neighborhood - kindergarten school" and promotes at the level of today's demand.

\section{RESULT AND DISCUSSION}

Developed in 1993 to unite the efforts of the participants in the educational process, the Concept " Partnership of family, mahalla (neighborhood), educational entities" has become a program to coordinate the activities of the general public in upbringing young people to be loyal to the ideas of independence, spiritually mature and patriotic.

In order to increase the social activeness of young people, it is expedient to provide pedagogical knowledge to parents on the basis of school-neighborhood cooperation. In the implementation of pedagogical education, it is important not only to educate parents, but also to equip them with practical skills and abilities in the field of education, to awaken their pedagogical thinking, to encourage independent practice, to establish family relationships in accordance with the purpose (in terms of upbringing).

Pedagogical lecture is one of the most popular forms of pedagogical education. 
Recently, pedagogical education of parents has become more widespread, and are carried out in various forms through pedagogical universities of parents in neighborhoods and enterprises, clubs, houses of culture, residences and so on.

It is advisable to give lectures for parents based on clear material, positive examples, using literary sources, slides and other visual aids. Parents' stories about family parenting experiences will be very interesting and understandable.

It is very useful to not only provide parents with pedagogical knowledge, but also teach them to be able to target their children, to know in advance what will come out of them, and to plan their upbringing.

The high educational and cultural level of our parents requires an increase in the quality of pedagogical and psychological exposure. In direct interaction with parents, it is possible to study the creative team work of educators in this area.

\section{CONCLUSION}

By referencing the proverb "Seven mahallas (neighborhoods) are both father and mother for each child" in his work "We will build our great future together with our brave and kind people", S.M.Mirziyoyev maintains that there is not, and will not be, a foreign child for us in this society. Therefore, if we show love to children in time, teach them science, profession, virtues, bring them up with free and independent thinking, they will become patriotic, enterprising and active members of our society. After all, young people are our future.
1. Mirziyoyev, S.M., (2017). "We will build our great future together with our brave and kind people”. Uzbekistan. Tashkent.

2. Mirziyoyev, S.M., (2017). "Critical analysis, strict discipline and personal responsibility should be a daily rule in each leader's performance". Uzbekistan. Tashkent.

3. Sources of Republic scientific-practical assembly, (2018). "Factors of increasing the youth's social activeness in developing civil society". Samarkand.

4. www.gazeta.uz

5. www.norma.uz 